\title{
HUBUNGAN SARANA PRASARANA OLAHRAGA TERHADAP MINAT SISWA DALAM PELAKSANAAN PEMBELAJARAN PENDIDIKAN JASMANI OLAHRAGA DAN KESEHATAN DI SMA N 1 BATIPUAH KABUPATEN TANAH DATAR.
}

\author{
Hasriwandi Nur ${ }^{1}$, Nirwandi ${ }^{2}$, Ali Asmi ${ }^{3}$
}

${ }^{1}$ Program Studi Pendidikan Jasmani Kesehatan dan Rekreasi, Fakultas Ilmu Keolahragaan, Universitas Negeri Padang. Jalan Prof. Dr. Hamka Air Tawar Barat, Padang, 25132, Indonesia. ${ }^{2}$ Program Studi Ilmu Keolahragaan, Fakultas Ilmu Keolahragaan, Universitas Negeri Padang. Jalan Prof. Dr. Hamka Air Tawar Barat, Padang, 25132, Indonesia.

${ }^{3}$ Program Studi Ilmu Keolahragaan, Fakultas Ilmu Keolahragaan, Universitas Negeri Padang. Jalan Prof. Dr. Hamka Air Tawar Barat, Padang, 25132, Indonesia.

\section{E-mail: deswandi@fik.unp.ac.id ${ }^{1}$, syafruddin@fik.unp.ac.id ${ }^{2},{\text { khairudin@ @fik.unp.ac.id }{ }^{3}}$}

\begin{abstract}
ABSTRAK
Masalah dalam penelitian ini berawal dari pengamatan yang penulis lakukan tentang minat siswa dalam pelaksanaan pembelajaran pendidikan jasmani olahraga dan kesehatan di SMA N 1 Batipuah Kabupaten Tanah Datar. Banyak faktor yang mempengaruhinya diantaranya adalah sarana prasarana yang ada dan disediakan oleh sekolah untuk kelangsungan pembelajaran Pendidikan Jasmani Olahraga dan Kesehatan di SMA N 1 Batipuah Kabupaten Tanah Datar. Kenyataannya bahwa dalam proses balajar mengajar, minat, aktivitas belajar dan sarana prasarana yang optimal sangat diperlukan oleh anak didik dalam usahanya untuk mencapai hasil belajar yang optimal. Lembaga pendidikan khususnya sekolah mempunyai tanggung jawab yang cukup besar dalam mengantisipasi masalah yang terjadi di lapangan,

Jenis penelitian adalah korelasi product moment. Populasi penelitian ini adalah seluruh siswa Di SMA N 1 Batipuah Kabupaten Tanah Datar yang berjumlah 354 orang siswa tahun pelajaran 2013/2014. Teknik pengambilan sampel menggunakan proposional random sampling proposi yang dipakai sebesar 10\% pada siswa Di SMA N 1 Batipuah Kabupaten Tanah Datar ( Suharsismi Arikunto, 1998:120), yaitu sebanyak : 35 orang siswa. Untuk memperoleh data dilakukan Kuesioner ( angket ) kedua variabel. Data dianalisis dengan korelasi product moment.

Berdasarkan hasil analisis data diperoleh, terdapat hubungan yang signifikan antara "sarana prasarana olahraga dengan minat siswa". Ini dibuktikan dengan hasil yang diperoleh $t_{\text {hitung }}=1,98>$ $t_{\text {tabel }}=1,70$, dengan kontribusinya 9,99\%. Dengan demikian dapat disimpulkan bahwa hipotesis penelitian diterima karena sarana prasarana olahraga dapat mempengaruhi minat siswa. Disarankan kepada pihak sekolah agar melengkapi sarana prasarana olahraga, dan kepada guru Penjasorkes hendaknya memberikan pembelajaran yang bervariasi kepada anak didiknya, agar minat siwa untuk belajar penjasorkes lebih meningkat.
\end{abstract}

Kata kunci : Sarana Prasarana, Minat Siswa

\section{PENDAHULUAN}

Pendidikan merupakan usaha untuk mengembangkan potensi dasar manusia, mempersiapkan sumber daya yang berkualitas, memiliki daya saing dan mampu menghadapi perubahan yang sangat pesat, untuk itulah pendidikan harus berorientasi ke masa depan yang memperhatikan tuntutan kemajuan zaman yang ditandai dengan persaingan yang sangat komplek.

Usaha mencapai tujuan pendidiakan dan prestasi olahraga, murid dihadapkan mampu mengembangkan secara optimal potensi diri termasuk dibidang olahraga. Pengembangan bidang olahraga mempunyai peranan penting dalam mewujudkan cita-cita pembangunan nasional, karena pengembangan itu diarahkan untuk pembentukan manusia Indonesia 
seutuhnya. Pendidikan nasional yang sehat jasmani dan rohani. Untuk mewujudkan pembangunan nasional di bidang pendidikan. Di dalam Garis-Garis Basar Haluan Negara (GBHN) Tahun 1999-2004 dijelas :

“(a) Menumbuhkan budaya olahraga guna meningkatkan kualitas manusia Indonesia sehingga memiliki tingkat kesegaran dan kebugaran yang cukup dan dimulai sejak dini melalui pendidikan olahraga disekolah dan masyarakat (b) Meningkatkan usaha pembibitan dan pembinaan olahraga prestasi harus dilakukan secara sistematis dan konfrehensif melalui lembaga-lembaga pendidikan sebgai pusat pembinaan di bawah koordinasi olahraga penyandang cacat bersama-sama dengan masyarakat demi tercapainya sasaran prestasi yang mengmbangkan ditingkat internasional".

Berdasarkan kutipan di atas, jelas bahwa olahraga merupakan sasaran untuk meningkatkan kualitas bangsa. Untuk itu olahraga perlu dibina melalui sejak dini agar dapat meningkatkan kesehatan dan kebugaran anak didik. Sekolah merupakan salah satu lembaga formal yang dalam menyelenggarakan aktivitasnya menuntut perlunya pengembangan potensi siswa seoptimal mungkin sehingga tercipta sumber daya manusia yang berkualitas.

Oleh sebab itu, sekolah harus mempunyai tujuan pendidikan bertujuan untuk mengembangkan kemampuan dan membina watak untuk mencerdaskan kehidupan bangsa dengan tujuan mengembangkan potensi anak didik agar selalu beriman dan berkawa kepada Tuhan Yang Maha Esa, yang memiliki akhlak mulia, jasmani dan rohani yang sehat serta mempunyai ilmu pengetahuan yang luas serta kreatif dalam berbagai bidang apapun dan bertanggung jawab terhadap bangsa dan negara sendiri.

Untuk melihat pembinaan dan pengembangan olahraga di sekolah dapat kita lihat dalam Undang Undang Republik Indonesia No. 3 (2005:5), tentang system keolahragaan pendidikan nasional: " pembinaan dan pengembangan olahraga, pendidikan dilaksanakan melalui proses pembelajaran yang dilakukan oleh guru olahraga yang berkualitas dan memiliki sertifikasi kompetensi serta didukung oleh sarana dan prasarana olahraga yang memadai”.
Dari Undang Undang di atas dapat kita tarik kesimpulan bahwa olahraga pendidikan di sekolah adalah olahraga yang membina serta mengembangkan kegiatan olahraga yang dilakukan melalui proses pembelajaran di sekolah yang dibimbing oleh guru olahraga yang memiliki kemampuan atau sertifikat di bidang tersebut serta didukung oleh adanya sarana dan prasarana yang mendukung terlaksananya kegiatan tersebut.

Pelajaran penjas merupakan salah satu mata pelajaran dari sekolah yang mulai diajarkan pada sekolah dasar sampai sekolah menengah umum bahkan sampai ke perguruan tinggi. Disekolah dasar pelajaran penjas belum diajarkan secara khusus, tetapi secara tidak langsung mereka telah mengenal dan mempelajari ilmu penjas.

Bagi siswa sekolah menengah umum mungkin pelajaran penjas sudah tidak asing lagi karena mereka telah memperoleh pengetahuan dasar tentang pelajaran penjas dengan baik, maka tidak sedikit diantara mereka yang merasakan bahwa pelajaran penjas sulit dipahami, sehingga dengan demikian siswa mau melakukan dan mempelajari pelajaran penjas.

Berdasarkan pemikiran di atas maka prestasi belajar penjas perlu adanya penataan dari berbagai segi antara lain dalam kaitannya dengan pengetahuan dasar siswa, cara belajar siswa dan juga kesiapan yang bersangkutan sebelum mengikuti suatu pelajaran.

Dunia pendidikan tidak akan berkembang tanpa memperbaiki proses belajar mengajar yang mampu mengembangkan tanpa memperbaiki proses belajar mengajar yang mampu mengembangkan daya kreativitas dan aktivitas siswa, sehingga memperoleh hasil yang maksimal.

Menciptakan kegiatan belajar mengajar yang mampu mengembangkan aktivitas dan hasil belajar yang maksimal merupakan sebagian tugas pengajar. Tetapi salah satu faktor yang dapat mempengaruhi rendahnya mutu pendidikan siswa adalah minat belajar siswa. Minat belajar merupakan masalah anak didik yang diterima baik disekolah maupun dirumah. Minat juga merupakan keadaan psikologis yang dapat mempengaruhi proses belajar dan hasil belajar siswa.

Kalau seseorang mempelajari sesuatu dengan penuh minat, maka diharapkan hasilnya akan lebih baik. Berhasil dan tidaknya proses belajar mengajar Pendidikan Jasmani dan Hubungan Sarana Prasarana Olahraga Terhadap Minat 94 
Kesehatan ditentukan oleh beberapa faktor yaitu faktor internal dan faktor eksternal. Faktor internal yaitu guru dan sarana dan prasarana Pendidikan Jasmani sebagai alat untuk menjalankan kegiatan belajar mengajar Sekolah.

Faktor eksternal yaitu meliputi faktor keluarga, faktor lingkungan dan faktor masyarakat Sarana dan prasarana pendidikan jasmani merupakan faktor penting dalam suksesnya pembelajaran pendidikan jasmani, Jadi sekolah seharusnya menyediakan sarana dan prasarana yang sesuai dan akan lebih bagus kalau setiap sekolah mempunyai sarana dan prasarana yang diperlukan dalam pengajaran pendidikan jasmani(Penjas).

Kurangnya sarana dan prasarana yang ada di Sekolah, maka seorang guru penjaskes dituntut untuk berkreatifitas dalam penyampaian materi dengan sarana dan prasarana yang kurang memenuhi. Dengan demikian di sekolah-sekolah seharusnya disediakan sarana dan prasarana yang seluas-luasnya agar pelaksanaan pendidikan jasmani dan kesehatan dapat berjalan sesuai dengan kurikulum yang ada.

Berdasarkan hasil observasi di lapangan ada di temui bahwa siswa kurang berminat dalam melakukan aktifitas penjas,mungkin ini di sebabkan oleh beberapa faktor yaitu berupa minat, sarana prasarana, motivasi, media pembelajaran dan guru. Kenyataannya bahwa dalam proses balajar mengajar, minat, aktivitas belajar dan sarana prasarana yang optimal sangat diperlukan oleh anak didik dalam usahanya untuk mencapai hasil belajar yang optimal. Lembaga pendidikan khususnya sekolah mempunyai tanggung jawab yang cukup besar dalam mengantisipasi masalah yang terjadi di lapangan tersebut.

\section{Sarana dan Prasarana olahraga}

a. Sarana olahraga

Sarana olahraga merupakan sesuatu yang dapat digunakan dan dimanfaatkan dalam pelaksanaan kegiatan olahraga atau pendidikan jasmani. Sarana olahraga dapat dibedakan menjadi dua kelompok yaitu : 1) Peralatan (apparatus), Peralatan adalah sesuatu yang digunakan, contoh : palang tunggal, palang sejajar, gelang-gelang, kudakuda, dan lain-lain. 2) Perlengkapan (device), perlengkapan merupakan sesuatu yang melengkapi kebutuhan prasarana, misalnya ; net, bendera untuk tanda, garis batas dan lainlain. Selain itu, perlengkapan juga bisa diartikan sebagai sesuatu yang dapat dimainkan atau dimanipulasi dengan tangan atau kaki, misalnya : bola, raket, pemukul dan lain- lain.

Sarana olahraga yang dipakai dalam kegiatan olahraraga pada masing- masing cabang olahraga memiliki ukuran yang standar. Akan tetapi apabila olahraga tersebut dipakai sebagai materi pembelajaran pendidikan jasmani, sarana yang digunakan bisa dimodifikasi, disesuaikan dengan kondisi sekolah dan karakteristik siswa. Di dalam pendidikan jasmani, sarana sederhana dapat digunakan untuk pelaksanaan materi pelajaran pendidikan jasmani yang tentunya dalam bentuk permainan, misalnya : bola kasti, bola tenis, potongan bambu, dan lain-lain.

b. Prasarana olahraga

Secara umum prasarana berarti segala sesuatu yang merupakan penunjang terselenggaranya suatu proses (usaha atau pembangunan). Dalam olahraga prasarana didefinisikan sebagai sesuatu yang mempermudah atau memperlancar tugas dan memiliki sifat yang relatif permanen. Salah satu sifat tersebut adalah susah dipindahkan. Berdasarkan definisi tersebut dapat disebutkan beberapa contoh prasarana olahraga adalah ; lapangan tenis, lapangan bola basket, gedung olahraga, lapangan sepakbola, stadion atletik, dan lain-lain.

Gedung olahraga merupakan prasarana berfungsi serba guna yang secara berganti-ganti dapat digunakan untuk pertandingan beberapa cabang olahraga. Gedung olahraga dapat digunakan sebagai prasarana pertandingan bola voli, prasarana olahraga bulutangkis dan lain-lain. Selain itu ada juga stadion atletik yang di dalamnya termasuk lapangan lompat jauh, lapangan lempar cakram, lintasan lari dan lain-lain. Seringkali stadion atletik digunakan sebagai prasarana pertandingan sepak bola yang memenuhi syarat pula, contohnya stadion utama di senayan.

Semua yang disebutkan di atas adalah contoh-contoh prasarana olahraga yang standar. Tetapi pendidikan jasmani seringkali hanya dilakukan di halaman sekolah atau di sekitar taman. Hal ini bukan karena tidak adanya larangan pendidikan jasmani dilakukan di halaman yang memenuhi standar, tetapi memang kondisi sekolahsekolah saat sekarang hanya sedikit yang memiliki prasarana olahraga yang standard.

Hubungan Sarana Prasarana Olahraga Terhadap Minat 95 
Tujuan diadakannya sarana dan prasarana adalah untuk memberikan kemudahan dalam mencapai tujuan pendidikan jasmani dan memungkinkan pelaksanaan program kegiatan belajar mengajar pendidikan jasmani (Abror Hisyam, 1991:3).

c. Faktor-faktor yang Mempengaruhi Pengadaan Sarana dan Prasarana Olahraga di Sekolah

Ada beberapa faktor yang mempengaruhi pengadaan sarana dan prasarana yang ada di sekolah yaitu : 1) Kurangnya sarana dan prasarana yang ada, pembelian sarana dan prasarana yang kurang kurang mendapatkan perhatian dari pihak sekolah sehingga mengakibatkan proses belajar mengajar menjadi terhambat. 2) Keadaan ekonomi sekolah, keadaan ekonomi yang lemah mengakibatkan sulit untuk membeli sarana dan prasarana yang sangat dibutuhkan sekolah, sementara bidang pendidikan yang lain juga membutuhkan dana dalam pelaksanaan belajar mengajar.

\section{Minat}

Minat merupakan masalah yang penting dalam pendidikan, apa lagi dikaitkan dengan aktivitas seseorang dalam kehidupan sehari-hari. Minat yang ada pada diri seseorang akan memberikan gambaran dalam aktivitas untuk mencapai tujuan. Di dalam belajar banyak siswa yang kurang berminat terhadap pelajaran yang diikutinya baik aktivitas praktek maupun teori untuk mencapai suatu tujuannya. Dengan diketahuinya minat seseorang akan dapat menentukan aktivitas apa saja yang dipilihnya dan bisa mengarahkan seseorang terhadap apa yang ingin dilakukannya maka penulis akan meneliti masalah ini agar didapatkan solusi untuk meningkatkan minat belajar siswa.

Minat sangat besar pengaruhnya terhadap belajar, karena bila bahan pelajaran yang dipelajari tidak sesuai dengan minat siswa maka siswa tidak akan belajar dengan sebaik-baiknya, karena tidak ada daya tarik tersendiri baginya. Sehingga siswa malas untuk belajar, siswa tidak memperoleh kepuasan dari pelajaran itu.

Bahan pelajaran yang menarik minat siswa, lebih mudah dipelajari dan disimpan karena minat siswa tersebut akan bertambah karena senang dengan pelajaran tersebut. Minat merupakan salah satu aspek psikis yang membantu dan mendorong seseorang untuk memenuhi kebutuhannya, maka minat harus ada dalam diri seseorang, sebab minat merupakan modal dasar untuk mencapai tujuan.
Dengan demikian minat harus menjadi pangkal permulaan dari pada semua aktivitas. Beberapa pengertian minat antara lain :

1) Menurut Hilgard dalam bukunya Slameto (2003:57) “ Minat adalah kecendurungan yang tetap untuk memperhatikan dan mengenang beberapa kegiatan yang diminati seseorang, diperhatikan terus-menerus yang disertai dengan rasa senang ".

2) Menurut Crow and Crow dalam bukunya Abd. Rachman Abror (1935:135) " Minat atau interest bisa berhubungan dengan daya gerak yang mendorong kita cenderung atau merasa tertarik pada orang, benda, atau kegiatan ".

3) Menurut Drs. Slameto (2003:180) “ Minat adalah suatu rasa lebih suka dan rasa keterikatan pada suatu hal atau aktivitas, tanpa ada yang menyuruh ".

Dari beberapa pendapat yang dikemukakan tersebut diatas, peneliti dapat menarik kesimpulan bahwa minat adalah kecendurungan hati seseorang yang terarah kepada suatu obyek tertentu yang dinyatakan dalam berbagai tindakan, karena adanya suatu perhatian dan perasaan tertarik pada obyek.

a. Ciri-Ciri Minat

Minat tidak dibawa sejak lahir, melainkan diperoleh kemudian. Seseorang harus mempelajari keadaan atau situasi terlebih dahulu, dari situ akan timbul minat dari dirinya dan kemudian minat tersebut akan mempengaruhi kegiatan berikutnya serta akan mempengaruhi minat-minat baru, artinya untuk menimbulkan minat, seseorang harus belajar terlebih dahulu untuk mengetahui keadaan yang akan diminatinya.

Jadi, minat terhadap sesuatu merupakan hasil belajar dan menyokong belajar selanjutnya. Walaupun minat terhadap sesuatu hal tidak merupakan hal yang hakiki untuk dapat mempelajari hal tersebut. Asumsi umum menyatakan bahwa minat akan membantu seseorang mempelajarinya. Dorongan-dorongan yang ada pada diri anak, menggambarkan perlunya perlakuan yang luas sehingga ciri-ciri dan minat anak tergambar lebih terinci dan faktual, sesuai dengan usia dan kedewasaan mereka.

Dengan demikian ciriciri dan minat anak akan menjadi pedoman penyelenggaraan program pendidikan jasmani dan arahannya

Hubungan Sarana Prasarana Olahraga Terhadap Minat 96 
dapat dikategorikan kedalam domain hasil belajar yaitu : psikomotor, afektif, kognitif dan domain yang lainnya. Dengan begitu kondisi belajar mengajar yang efektif adalah adanya minat dan perhatian siswa dalam belajar.

Minat merupakan suatu sifat yang relatif menetap pada diri sesorang. Minat ini besar sekali pengaruhnya terhadap belajar, sebab dengan minat seseorang akan melakukan sesuatu yang diminatinya. Misalnya seorang siswa menaruh minat terhadap bidang olahraga, maka siswa tersebut akan berusaha untuk mengetahui lebih banyak tentang olahraga.

Dengan digunakannya sebagai pedoman, maka pandangan dan pengembangan program akan sesuai dengan ketepatan masa belajar, urutan, kecepatan dan ragam kegiatan yang akhirnya akan mendapatkan hasil yang diinginkannya.

Dalam hal ini dianjurkan untuk tidak menggunakannya pendekatan yang telah terbiasa yaitu pilihan kegiatan berdasarkan anjuran guru sebab pendekatan yang demikian akan berdampak terhadap keterbatasan pandangan siswa, karena kalau berdasarkan anjuran dari guru seolah-olah kegiatan itu sekedar memenuhi kebutuhan guru, bukan kebutuhan siswa.

\section{Pendidikan Jasmani}

\section{a. Pengertian pendidikan jasmani}

Jasmani adalah kata sifat yang berasal dari kata jasad yang berarti tubuh atau badan. Pendidikan Jasmani adalah bagian integral dari pendidikan dan merupakan alat pendidikan. Pendidikan Jasmani merupakan usaha pendidikan dengan menggunakan aktivitas otot-otot besar hingga proses pendidikan yang berlangsung tidak terhambat oleh gangguan kesehatan dan pertumbuhan badan, selaim itu pendidikan jasmani juga sebagai bagian integral dari proses pendidikan keseluruhan. Pendidikan jasmani merupakan usaha yang bertujuan untuk mengembangkan kawasan organik, neuromuskuler, intelektual dan sosial.

Dengan pandangan ini maka pendidikan jasmani berkaitan dengan perasaan, hubungan pribadi, tingkah laku kelompok, perkembangan mental dan sosial, intelektual dan estetika. Dalam Pendidikan jasmani, meskipun seseorang berusaha untuk mendidik manusia melalui sarana jasmani dengan aktivitas-aktivitas jasmani atau aktivitas fisik namun tetap berkepentingan dengan tujuan pendidikan yang tidak semuanya jasmani atau fisik.

b. Tujuan Pendidikan Jasmani

Pendidikan jasmani adalah pergaulan pedagogik dalam dunia gerak dan penghayatan jasmani. Juga dikatakan bahwa guru pendidikan jasmani mencoba mencapai tujuannya mengajarkan dan memajukan aktivitasaktivitas jasmani. Pendidikan jasmani menampakan dirinya keluar sebagai pengajaran dalam latihan jasmani atau sebagai pengajaran gerak.

Isi dari aspek pendidikan ini ditentukan oleh intensi-intensi pedagogik atau tujuan pendidikan yang dipakai sebagai pegangan oleh guru pendidikan jasmani. Sesuai dengan berbagai modalitas dari hubungan manusia dengan dunianya, dengan benda-benda, dengan orang lain dan dengan dirinya sendiri maka tujuantujuan yang dapat diraih adalah sebagai berikut:

a) Pembentukan Gerak

1) Memenuhi serta mempertahankan keinginan gerak.

2) Penghayatan ruang, waktu dan bentuk serta pengembangan perasaan irama.

3) Mengenal kemungkinan gerak diri sendiri.

4) Memiliki keyakinan gerak dan mengembangkan perasaan sikap.

5) Memperkaya dan memperluas kemampuan gerak dengan melakukan pengalaman gerak.

b) Pembentukan Prestasi

1) Mengembangkan kemampuan kerja optimal dengan mengajarkan ketangkasanketangkasan.

2) Belajar mengarahkan diri pada pencapaian prestasi (Kemauan, Konsentrasi, Keuletan, Kewaspadaan, Kepercayaan pada diri sendiri).

3) Penguasaan emosi.

4) Belajar mengenal kemampuan dan keterbatasan diri.

5) Meningkatkan sikap tepat terhadap nilai yang nyata dari tingkat dan bidang prestasi, dalam kehidupan sehari-hari, dalam masyarakat dan dalam olahraga.

c) Pembentukan Sosial

1) Pengakuan dan penerimaan peraturanperaturan dan norma-norma bersama.

2) Mengikut sertakan kedalam struktur kelompok fungsional, belajar bekerja sama, menerima pemimpin dan memberikan pimpinan. 
3) Pengembangan perasaan kemasyarakatan dan pengakuan terhadap orang lain sebagai pribadi-pribadi.

4) Belajar bertanggung jawab terhadap yang lain, memberi pertolongan, memberi perlindungan dan berkorban.

5) Belajar mengenal dan mengalami bentukbentuk pelepas lelah secara aktif untuk pengisian waktu senggang.

d) Pertumbuhan Badan

1) Peningkatan syarat-syarat yang diperlukan untuk dapat tumbuh, bersikap dan bergerak dengan baik dan untuk dapat berprestasi secara optimal (kuatan dan mobilitas, pelepasan ketegangan dan kesiap siagaan).

2) Meningkatkan kesehatan jasmani dan rasa tanggung jawab terhadap kesehatan diri dengan menbiasakan cara-cara hidup sehat.

Tak ada pendidikan jasmani yang tidak bertujuan pendidikan. Tak ada pendidikan yang lengkap tanpa pendidikan jasmani, sebab gerak adalah dasar untuk belajar mengenal dunia dan diri sendiri

\section{METODE}

Jenis penelitian ini adalah korelas product moment yang bertujuan untuk mengungkap bagaimana "Hubungan Sarana Prasarana Olahraga Terhadap Minat Siswa Dalam Pelaksanaan Pembelajaran Pendidikan Jasmani Olahraga Dan Keseharan Di SMA N 1 Batipuah". Variabel dalam penelitian ini adalah Saran Prasarana Olahraga sebagai variabel bebas dan Minat Siswa Dalam Pelaksanaan Pembelajaran Penjas sebagai variabel terikat. Penelitian ini dilakukan Di SMA N 1 Batipuah. Waktu penelitian ini dilakukan pada bulan November sampai dengan bulan Desember 2013..

Populasi merupakan keseluruhan subjek penelitian. (Suharsimi Arikunto, 1998:115). Penelitian populasi dilakukan apa bila peneliti ingin meneliti semua elemen yang ada. Populasi dalam penelitian ini adalah seluruh siswa SMA N 1 Batipuah yang berjumlah : 354 Siswa.

Sampel adalah sebagian atau wakil populasi yang diteliti (Suharsimi Arikunto, 1998:117). Berpedoman pada populasi yang ada, maka sampel diambil secara proposional random sampling, proporsi yang dipakai sebesar $10 \%$ pada siswa SMA N 1 Batipuah (Suharsimi Arikunto, 1998:120), yaitu sebanyak : 35 siswa
Jenis data yang diperlukan dalam penelitian ini adalah data primer yang diambil dari responden melalui angket dan data sekunder dari berbagai sumber data yang tidak langsung diperoleh pada objek penelitian. ini adalah siswa di SMA N 1 Batipuah Kabupaten Tanah Datar.

Untuk memperoleh data yang penulis perlukan dalam penelitian ini, maka teknik dan alat pengumpulan data yang penulis pergunakan adalah kuesioner. Kuesioner (angket) digunakan untuk mendapat informasi tentang Hubungan Sarana Prasarana Olahraga Terhadap Minat Siswa Dalam Pelaksanaan Pembelajaran Pendidikan Jasmani Olahraga Dan Kesehatan Di SMA N 1 Batipuah.

Sebelum penyebaran kuesioner ini dilakukan, telah disiapkan dan disusun langkahlangkah yang sistematis agar data yang diperoleh sesuai dengan yang diharapkan. Langkahlangkah tersebut adalah berupa kisi-kisi angket.

Tabel . Kisi-Kisi Penelitian

\begin{tabular}{|c|c|}
\hline Variabel & Indikator \\
\hline $\begin{array}{l}\text { Hubungan Sarana Prasarana } \\
\text { Olahraga Terhadap Minat Siswa } \\
\text { Dalam Pelaksanaan Pembelajaran } \\
\text { Pendidikan Jasmani Olahraga Dan } \\
\text { Keseharan Di SMA N } 1 \text { Batipuah }\end{array}$ & $\begin{array}{l}\text { Sarana Prasarana } \\
\text { Olahraga } \\
\text { Minat Siswa }\end{array}$ \\
\hline
\end{tabular}

\section{Instrument penelitian}

Instrumen merupakan alat bantu dalam pengumpulan data. Instrumen pengumpulan data pada penelitian ini yaitu instrumen minat belajar siswa mengikuti mata pelajaran penjas yang berupa angket. Sedangkan untuk sarana prasarana olahraga siswa diperoleh dari observasi.

Selanjutnya untuk mendapatkan data dalam penelitian ini. Peneliti menggunakan angket sebagai pengumpul data dan disusun dengan menggunakan Skala Likert yang terdiri dari lima kategori apabila pernyataan positif maka nilainya yaitu, Sangat Setuju (SS): 5, Setuju (S): 4, Ragu-Ragu (RR): 3, Tidak Setuju (TS): 2, dan Sangat Tidak Setuju (STS): 1. Dan jika pernyataannya negatif maka penilaiannya yaitu :Sangat Setuju (SS):1, Setuju (S):2, RaguRagu (RR): 3, Tidak Setuju (TS): 4, dan Sangat Tidak Setuju (STS): 5.

Dengan kriteria nilai tingkat pencapaian responden yang diklasifikasikan 
oleh Sudjana (1996:355) yakni sebagai berikut:

\section{Teknik Analisis data}

Data yang diperoleh dalam penelitian ini akan diolah dengan teknik analisis korelasi produc moment.

Dengan rumus :
Berdasarkan Tabel 2, terlihat bahwa rata- rata kelompok terbanyak terdapat pada interval 7,62-8,42 sebanyak 14 buah, diikuti interval 8,43 9,23 sebanyak 8 buah, interval 9,2410,04 sebanyak 7 buah, interval 6,81 7,61 sebanyak 4 buah dan interval 6,006,80 sebanyak 2 buah. Untuk lebih jelasnya dapat dilihat pada Gambar 2

$$
\begin{aligned}
& r \times y=\frac{n \sum x y-2}{\sqrt{ } n \sum x^{2}-\left(\sum x\right)^{2}} \\
& \text { Keterangan: } \\
& \text { rxy = koefisien korelasi antar variabel } \\
& \quad \begin{array}{l}
\text { X (skor subjek tiap butir) } \\
\text { dengan variabel Y (total skor }
\end{array} \\
& \quad \text { subjek dari keseluruhan butir). } \\
& \mathrm{x}=\text { Variabel bebas } \\
& \mathrm{y}=\text { Variabel terikat } \\
& \mathrm{n}=\text { Jumlah sampel }
\end{aligned}
$$

\section{HASIL DAN PEMBAHASAN}

\section{A. Deskripsi Data}

Variabel penelitian ini terdiri dari Sarana Prasarana o1ahraga (X) dan Minat Siswa (Y). Masing- masing varibel akan dideskripsikan nilai rata- rata (mean), simpanan baku (standar deviasi), median, modus, distribusi, frekuensi dan histogram. Dari jumlah sampel yang direncanakan sebanyak 35 orang responden, penulis mampu menemukan seluruh responden dan membagikan angket penelitian dengan baik.

\section{Sarana Prasarana O1ahraga}

Dari data penelitian skor dari sarana prasarana olahraga diperoleh Range sebesar 4 dengan skor terendah 6 dan skor tertinggi 10. Dari analisa data diketahui skor rata- rata sebesar 8,4, simpanan baku 1,11 , median 8 , modus 8 dan luas kelas interval 0,80 .

$$
\text { Tabel } 2
$$

Distribusi Frekuensi Skor Variabel Sarana prasarana olahrgaa

\begin{tabular}{|c|c|c|c|}
\hline No & Kelas Interval & Frekuensi & Persentase (\%) \\
\hline 1 & $6,00-6,80$ & 2 & 5,71 \\
\hline 2 & $6,81-7,61$ & 4 & 11,43 \\
\hline 3 & $7,62-8,42$ & 14 & 40,00 \\
\hline 4 & $8,43-9,23$ & 8 & 22,86 \\
\hline 5 & $9,24-10,04$ & 7 & 20,00 \\
\hline \multicolumn{2}{|r|}{ Jumlah } & 35 & 100,00 \\
\hline
\end{tabular}

$x)\left(\sum^{\text {berikyt }}\right.$

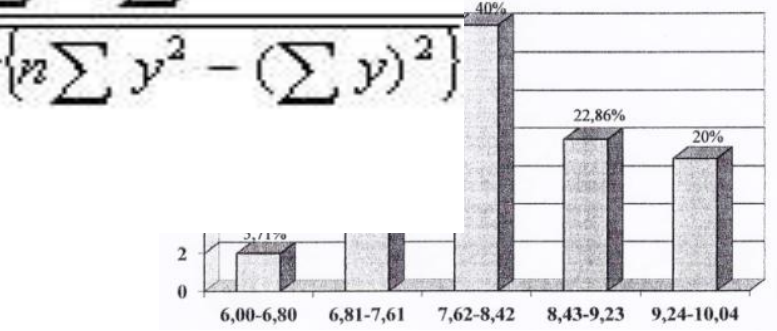

Gambar 2. Histogram Variabel

Sarana Prasarana Olahraga

\section{Minat Siswa}

Dari data penelitian skor minat Siswa diperoleh Range sebesar 5 dengan skor terendah 5 dan skor tertinggi sebanyak 10. Dari analisa data diketahui skor rata- rata sebesar 7,3, simpangan baku 1,19 , median 7 , modus 8 dan luas kelas interval 1.

Adapun distribusi frekuensi skor minat Siswa sebagaimana tampak pada Tabe1 3 berikufini 3

Distribusi Frekuensi Skor Variabel Minat Siswa

\begin{tabular}{|c|c|c|c|}
\hline No & Kelas Interval & Frekuensi & Persentase (\%) \\
\hline 1 & $5-6$ & 7 & 20,00 \\
\hline 2 & $7-8$ & 23 & 65,71 \\
\hline 3 & $9-10$ & 5 & 14,29 \\
\hline \multicolumn{2}{|c|}{ Jumlah } & 35 & 100,00 \\
\hline
\end{tabular}

Berdasarkan Tabel 3, terlihat bahwa ratarata kelompok terbanyak terdapat pada interval 7-8 sebanyak 23 buah, diikuti interval 5-6 sebanyak 7 buah dan interval 9-10 sebanyak 5 buah. Untuk lebih jelasnya dapat dilihat pada Gambar 3 berikut ini.

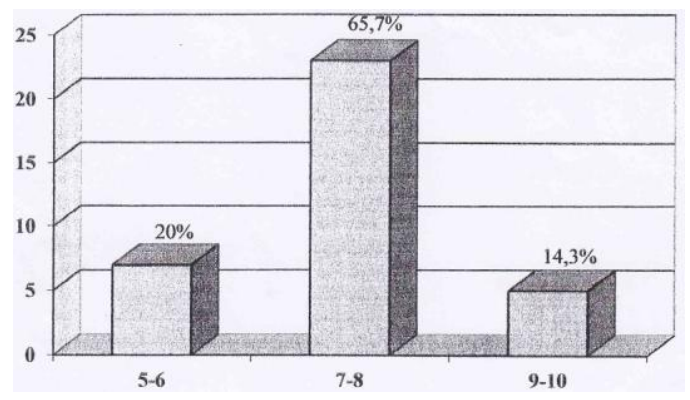

Hubungan Sarana Prasarana Olahraga Terhadap Minat 99 
Gambar 3. Histogram Variabel Minat Siswa

\section{B. Pengajuan Persyaratan Analisis}

Persyaratan analisis yang dimaksud adalah persyaratan yang harus dipenuhi sebelum melakukan analisis korelasi, persyaratan analisis tersebut adalah uji normalitas. Berikut penjelasan pengujian Normalitas :

Tujuan pengujian normalitas yaitu untuk menguji asumsi bahwa distribusi sampling data mendekati atau mengikuti normalitas populasi. Keadaan sampling yang normal penting karena merupakan persyaratan penggunaan statistic untuk pengujian hipotesis. Teknik yang digunakan dalam pengujian normalitas dalam penelitian ini adalah menggunakan Uji Kolmogorov Sminov $(K S)$.

Berdasarkan perhitungan pengujian normalitas yang dilakukan terhadap data 35 responden dari masingmasing variabel, diperoleh bahwa untuk variabel Sarana Prasarana Olahraga nilai KS adalah 1,25 dengan nilai siginifikansi sebesar 0.088. Nilai KS untuk variabel Minat Siswa adalah 1,10 dengan nilai signifkansi sebesar 0. 176.

Untuk pengambilan keputusan bahwa data berdistribusi normal, digunakan ketentuan berikut bahwa data berdistribusi normal jika nilai KS $>\alpha$. Berdasarkan data di atas maka dapat diambil kesimpulan sebagai berikut, untuk variabel Sarana Prasarana Olahraga nilai KS adalah 1,25 , dan jika dibandingkan dengan $\alpha$ maka nilai $\mathrm{KS}$ variabel Sarana Prasarana Olahraga besar dari $\alpha=0,05$. Untuk variabel Minat Siswa nilai KS adalah 1,10 , dan jika dibandingkan dengan o maka nilai KS variabel Minat Siswa besar dari $\alpha=$ 0,05. Maka dapat ditarik kesimpulan bahwa kedua variabel berdistribusi normal dan data tersebut dapat digunakan untuk pengujian korelasi. Lebih lengkapnya dapat dilihat pada table berikut:

Tabel 4

Uii Normalitas

\begin{tabular}{|c|c|c|c|}
\hline & & $\begin{array}{l}\text { Sarana Prasar } \\
\text { ana Olahraga }\end{array}$ & Minat_Siswa \\
\hline $\mathrm{N}$ & & 35 & 35 \\
\hline Norm Ploper & Mean & 8.4000 & 7,3429 \\
\hline Normal Parameters $(a, b)$ & Std. Deviation & 1,11672 & 1,18676 \\
\hline \multirow{3}{*}{$\begin{array}{l}\text { Most Extreme } \\
\text { Differences }\end{array}$} & Absolute & .211 & .186 \\
\hline & Positive & 211 & 157 \\
\hline & Negative & -189 & -186 \\
\hline Kolmogorov-Smirnov Z & & 1,250 & 1,102 \\
\hline Asymp. Sig. (2-tailed) & & 088 & .176 \\
\hline
\end{tabular}

\section{Pengujian Hipotesis}

Setelah uji persyaratan analisa dilakukan dan ternyata memenuhi persyaratan- persyaratan untuk dilakukan dan pengajuan statistic yaitu :

\section{Korelasi Product Moment.}

Analisa korelasi terhadap skor Sarana Prasarana Olahraga dengan skor Minat siswa menghasilkan korelasi Produck Moment sebesar 0.315 dengan signifikansi sebesar 0,065. Untuk lebih lanjut hasil pengujian hipotesis dapat dilihat pada Tabel 5 di bawah ini :

Tabel 5

Hasil Pengujian Hipotesis Correlations

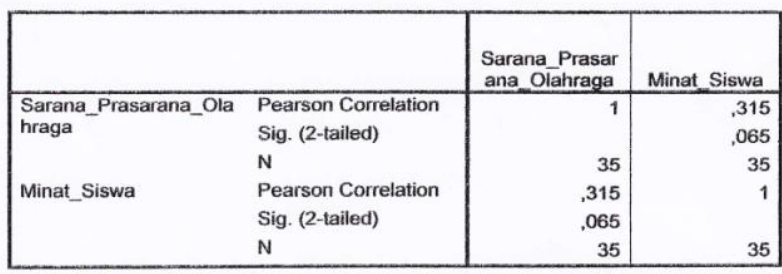

Berdasarkan uji keberartian korelasi antara variabel Sarana Prasarana Olahraga dengan Minat Siswa sebagaimana terlihat pada Tabel 5 diperoleh nilai signifikansi sebesar 0,065 . pengambilan keputusan keberartian korelasi yaitu dengan membandingkan nilai signifikansi dengan $\alpha=0,05$ dengan ketentuan bahwa $\mathrm{H}_{0}$ ditolak jika nilai signifikansi $<$ dari $\alpha$. Untuk melakukan uji hipotesi maka digunakan rumus sebagai berikut:

Oleh karena th, $,_{\mathrm{w}},,_{\mathrm{g}}(1,98)>\mathrm{t}_{\mathrm{t}}, \mathrm{k}$ ? $(1,70)$ maka $\mathrm{H}_{0}$ ditolak, dan $\mathrm{H}_{\mathrm{a}}$ diterima. Dengan demikian dapat disimpulkan bahwa terdapat pengaruh yang signifikan antara variabel bebas dengan variabel terikat. Dengan kata lain terdapat pengaruh yang berarti antara Sarana Prasarana Olahraga dengan Minat Siswa.

\section{Pembahasan}

Analisis deskripsi menunjukkan Hubungan Sarana Prasarana Olahraga Terhadap Minat 100 
bahwa terdapat 35 orang responden memperoleh skor kelompok rata- rata dari skor Sarana Parasana Olahraga, 15 orang responden yang memperoleh skor di atas harga rata- rata, 14 orang responden yang memperoleh dalarn harga rata- rata dan 6 orang responden memperoleh skor di bawah harga ratarata. Dengan demikian dapat disimpulkan bahwa Sarana Prasarana Olahraga Siswa Dalam Pelaksanaan Pembelajaran Penjas Di SMA N 1 Batipuah Kabupaten Tanah Datar dapat dikatakan sudah baik.

Sedangkan untuk skor Minat Siswa dari 35 orang responden memperoleh skor kelompok rata- rata dari skor Minat Siswa, 16 orang responden memperoleh skor di atas harga rata- rata, 12 orang responden yang memperoleh dalam harga rata- rata dan 7 orang responden memperoleh skor dibawah rata- rata. Dengan demikian, dapat dinyatakan bahwa Minat Siswa Dalam Pelaksanaan Pembelajaran Penjas Di SMA N 1 Batipuah Kabupaten Tanah Datar dapat dikatakan sudah baik.

Dari hasil pengujian hipotesis, temuan penelitian ini menunjukan bahwa terdapat pengaruh yang berarti antara sarana Prasarana Olaharaga dengan Minat siswa Dalam Pelaksanaan Pembelajaran Penjas Di SMA N 1 Batipuah Kabupaten Tanah Datar. Besar koefesien korelasi antara Sarana Prasarana Olahraga dengan Minat Siswa adalah 0.315. Kontribusi yang disumbangkan Sarana Prasarana Olahraga terhadap Minat Siswa Dalam Pelaksanaan Pembelajaran Penjas Di SMA N 1 Batipuah Kabupaten Tanah Datar adalah 9,9\%.

Sarana Prasarana olahraga merupakan sesuatu yang dapat digunakan dan dimanfaatkan dalam pelaksanaan kegiatan olabraga atau pendidikan jasmani. Sarana olahraga dapat dibedakan menjadi dua kelompok yaitu : 1) Peralatan (apparatus) Peralatan adalah sesuatu yang digunakan, contoh : palang tunggal, palang sejajar, gelang-gelang, kuda-kuda, dan lain-lain. 2) Perlengkapan (device), perlengkapan adalah sesuatu yang melengkapi kebutuhan prasarana, misalnya ; net, bendera untuk tanda, garis batas dan lain-lain.

Minat merupakan masalah yang penting dalam pendidikan, apa lagi dikaitkan dengan aktivitas seseorang dalam kehidupan sehari-hari. Minat yang ada pada diri seseorang akan memberikan gambaran dalam aktivitas untuk menecapai tujuan. Di dalam belajar banyak siswa yang kurang berminat dan yang berrninat terhadap pelajaran termasuk didalamnya adalah aktivitas praktek maupun teori untuk mencapai suatu tujuannya. Dengan diketahuinya minat seseorang akan dapat menentukan aktivitas apa saja yang dipilihnya dan akan melakukanya dengan senang hati.

Minat sangat besar pengaruhnya terhadap belajar, karena bila bahan pelajaran yang dipelajari tidak sesuai dengan minat siswa maka siswa tidak akan belajar dengan sebaik-baiknya, karena tidak ada daya tarik tersendiri baginya. Sehingga siswa malas untuk belajar, karena siswa tidak memperoleh kepuasan dari pelajaran itu. Bahan pelajaran yang menarik minat siswa, lebih mudah dipelajari dan disimpan karena minat menambah kegiatan belajar.

Minat merupakan salah satu aspek psikis yang membantu dan mendorong seseorang untuk memenuhi kebutuhannya, maka minat harus ada dalam diri seseorang, sebab minat merupakan modal dasar untuk mencapai tujuan.

Dari penjelasan di atas dapat disimpulkan bahwa den pentingnya sarana prasarana olahraga dan minat siswa dalam pelaksanaan pembelajaran penjas di SMA N 1 Batipuah Kabupaten Tanah Datar adalah untuk mencapai sebuah tujuan proses pembelajaran pendidikan Penjas yang kondusif, dan diharapkan supaya lebih meningkatkan minat siswa dan melengkapi sarana prasana olahraga.

\section{Kesimpulan}

Dari penelitian yang dilakukan untuk melihat Hubungan Sarana Prasarana Olahraga Terhadap Minat Siswa Dalam Pelaksanaan Pembelajaran Pendidikan Jasmani Olahraga kesehatan Di SMA N 1 Batipuah Kabupaten Tanah Datar, dapat ditarik beberapa kesimpulan:

Hubungan Sarana Prasarana Olahraga Terhadap Minat 101 
1. Data skor sarana prasarana olahraga diperoleh rentangan skor sebesar 4 dengan skor terendah 6 dan skor tertinggi 10. Dari analisis data diketahui skor ratarata sebesar 8,4, simpangan baku 1,11 median 8, modus 7 dan luas kelas interval 0,80 .

2. Data skor minat siswa diperoleh rentangan skor sebesar 5 dengan skor terendah 5 dan skor tertinggi 10. Dari analisis data dieketahui skor rata-rata sebesar 7,3, simpangan baku 1,10, median 7, modus 7 dan luas kelas interval 1.

3. Terdapat hubungan yang berarti sarana prasarana olahraga terhadap minat siswa dalam pelaksanaan pembelajaran pendidikan jasmani kesehatan, rekreasi dan olahraga Di SMA N 1 Batipuah Kabupaten Tanah Datar. Besar koefisien

4. korelasinya adalah 0,315 dan kontribusi $9,9 \%$.

Berdasarkan temuan penelitian ini, maka peneliti mengemukakan beberapa saran kepada berbagai pihak sebagai berikut:

1. Bagi kepala sekolah di Di SMA N 1 Batipuah Kabupaten Tanah Datar agar dapat melengkapi sarana prasaran olahraga.

2. Bagi guru Penjasorkes hendaknya merencanakan proses belajar mengajar yang bervariasi guna meningkatkan minat siswa terhadap belajar penjasorkes.

3. Berdasarkan hasil penelitian di dapat bahwa sarana prasarana olahraga berkontribusi sebesar 9,9\%. Ini berarti bahwa masih ada faktor lain yang mempengaruhi minat siswa, untuk itu diharapkan ada penelitian selanjutnya yang akan mengungkap faktor lain yang berhubungan dengan minat siswa. 